\title{
EFEK PEMUASAAN DAN PERTUMBUHAN KOMPENSASI PADA BENIH IKAN BAUNG (Hemibagrus nemurus)
}

\author{
Wahyulia Cahyanti, Vitas Atmadi Prakoso, Jojo Subagja, dan Anang Hari Kristanto \\ Balai Penelitian dan Pengembangan Budidaya Air Tawar \\ Jl. Raya Sempur No. 1, Bogor 16154 \\ E-mail : vitas.atmadi@gmail.com
}

\begin{abstract}
ABSTRAK
Ikan baung (Hemibagrus nemurus) merupakan salah satu ikan perairan umum yang bernilai ekonomi cukup baik. Berdasarkan informasi potensi tersebut, budidaya ikan baung perlu terus dikembangkan. Permasalahan yang sering muncul pada usaha budidaya ikan baung yakni biaya pakan buatan (pellet). Biaya untuk pakan buatan sangat mahal, sehingga dalam kegiatan budidaya ikan baung harus diperhatikan teknik pemberian pakannya. Metode untuk menurunkan biaya pakan adalah dengan cara pemberian pakan yang efektif. Salah satunya adalah dengan cara pemuasaan pakan. Penelitian ini bertujuan untuk menguji efek dari pemuasaan dan pertumbuhan kompensasi serta sintasan pada benih ikan baung. Penelitian menggunakan rancangan acak lengkap (RAL) dengan tiga perlakuan (A: 1 hari puasa 1 hari diberi pakan, B: 2 hari puasa 1 hari diberi pakan, dan C: kontrol (tiap hari diberi pakan)) dan 3 kali ulangan. Parameter yang dianalisis adalah pertumbuhan panjang mutlak, pertumbuhan bobot mutlak, laju pertumbuhan harian dan sintasan. Hasil penelitian menunjukkan benih ikan baung kontrol memiliki pertumbuhan panjang mutlak tertinggi $(1,17 \pm 0,35 \mathrm{~cm})$. Untuk pertumbuhan bobot mutlak ikan baung tertinggi didapatkan pada perlakuan B. Laju pertumbuhan harian tertinggi diperoleh pada perlakuan B $(0,95 \pm$ $0,34 \%)$ dan berbeda nyata $(\mathrm{P}<0,05)$ dengan perlakuan lainnya. Hasil pengujian menunjukkan perlakuan kontrol memiliki kelangsungan hidup yang berbeda nyata dengan perlakuan lain, dengan nilai $91,11 \pm 3,05 \%$. Benih ikan baung tidak dapat mencapai pertumbuhan kompensasi meskipun telah dipuasakan dalam waktu yang sangat singkat (1-2 hari). Pemuasaan juga berakibat pada semakin rendahnya tingkat kelangsungan hidup benih ikan baung akibat kanibalisme.
\end{abstract}

KATA KUNCI : Hemibagrus nemurus, pemuasaan, pertumbuhan, sintasan

ABSTRACT : $\quad$ Effects of feed-deprivation and compensatory growth on the seedling of Asian redtail catfish (Hemibagrus nemurus). By: Wahyulia Cahyanti, Vitas Atmadi Prakoso, Jojo Subagja, and Anang Hari Kristanto

Asian Redtail Catfish (Hemibagrus nemurus) is one of fish species that has good economic value. According to its potential information, aquaculture of this species should be developed. One of the problem regarding Asian Redtail catfish farming is the cost of artificial feed (pellets). Costs for artificial feed is very expensive, so in catfish farming activities must be considered techniques of feed. A method to reduce the cost of feed is by feeding effective. One of them is to feed gratification. This research aimed to examine the effects of feed-deprivation and compensatory growth and survival rate on the seedling of Asian Redtail Catfish. The study used a completely randomized design (CRD) with three treatments: (A) deprived of feed for one day, (B) deprived of feed for 2 days, and (C) control (without feed-deprivation)) and three replications. Length and weight gain, specific growth rate and survival rate calculated and analyzed stastically. The results showed catfish seeds had the highest length gain $(1.17 \pm 0.35 \mathrm{~cm})$ in control treatment. The highest weight gain was obtained in treatment $B$. The highest specific growth rate was obtained in treatment $B(0.95 \pm 0.34 \%)$ and significantly $(P<0.05)$ with others. The control treatment had significantly different survival rate with other treatments, with the values of $91.11 \pm 3.05 \%$. The seedling of Asian redtail catfish cannot achieve the compensatory growth despite having deprived in a very short time (1-2 days). Feed-deprivation was also resulted on increasingly lower survival rate of seedling by cannibalism.

KEYWORDS: Hemibagrus nemurus, feed-deprivation, growth, survival rate

\section{PENDAHULUAN}

Ikan baung (Hemibagrus nemurus) adalah ikan perairan umum yang mempunyai nilai ekonomi cukup baik di masa mendatang, sehingga perlu dipikirkan cara untuk budidaya ikan baung. Ikan baung termasuk ke dalam golongan omnivora yang cenderung ke karnivora, sehingga kebutuhan pakan lebih banyak ke bahan hewani, seperti cacing sutra, udang, dan pelet yang memiliki kandungan protein yang cukup 
tinggi dan baik untuk pertumbuhan benih ikan baung (Sucipto \& Prihartono, 2000)

Permasalahan yang sering muncul pada usaha budidaya ikan baung yakni biaya pakan buatan (pellet). Biaya untuk pakan buatan sangat mahal, sehingga dalam kegiatan budidaya ikan baung harus diperhatikan teknik pemberian pakannya. Teknik pemberian pakan yang kurang tepat akan meningkatkan biaya produksi ikan tersebut (Dwiyono, 2004). Metode untuk menurunkan biaya pakan adalah dengan cara pemberian pakan yang efektif. Salah satu cara yang dapat dilakukan yaitu dengan mengetahui pertumbuhan kompensasi dari ikan. pertumbuhan kompensasi didefinisikan sebagai fase pertumbuhan yang luar biasa cepat, menyusul periode kekurangan nutrisi (Hayward et al., 1997).

Beberapa penelitian tentang pertumbuhan kompensasi telah dilakukan pada beberapa spesies ikan. Ali et al. (2001) telah melakukan penelitian tentang pemuasaan ikan pada beberapa jenis ikan (Gasterosteus aculeatus, Phoxinus phoxinus, dan Carassius auratus gibelio), dan menunjukkan adanya pertumbuhan kompensasi. Penelitian lainnya oleh Walter et al. (2013) yang melakukan penelitian tentang pemuasaan pada yuwana ikan Atlantic cod menunjukkan bahwa hasil pertumbuhan terbaik diperoleh pada perlakuan tiga minggu puasa dan enam minggu diberi pakan, dibandingkan seminggu puasa seminggu diberi pakan. Selain itu, Wang et al. (2000) juga menemukan adanya pertumbuhan kompensasi pada ikan nila hibrid (Oreochromis mossambicus $\times 0$. niloticus). Menurut Hitchcock (2013), dengan menggunakan pertumbuhan kompensasi, petani dapat mengurangi biaya tanpa mengurangi hasil panen.

Meskipun telah banyak penelitian tentang pertumbuhan kompensasi, akan tetapi belum ditemukan informasi pada ikan baung. Ikan baung dikenal memiliki sifat tersendiri atau saling memangsa, sehingga ikan baung dikategorikan ikan kanibal, karena ikan ini pada saat lapar tidak segan-segan untuk memakan temannya sendiri.

Informasi mengenai efek pemuasaan benih ikan baung terhadap pertumbuhan kompensasinya sangat diperlukan. Penelitian ini bertujuan untuk menguji efek dari pemuasaan dan pertumbuhan kompensasi serta sintasan pada benih ikan baung.

\section{BAHAN DAN METODE}

Penelitian ini dilaksanakan pada bulan April - Mei 2015 di Laboratorium Basah, Balai Penelitian dan Pengembangan Budidaya Air Tawar, Bogor. Penelitian ini menggunakan pendekatan kuantitatif berdasarkan analisis pertumbuhan dan sintasan benih.

Ikan yang digunakan yaitu benih ikan baung ukuran 3-5 cm dengan kepadatan ikan pada masingmasing akuarium sebanyak 150 ekor. Ikan dipelihara di akuarium dalam sistem resirkulasi berjumlah 9 buah. Ukuran akuarium yang digunakan yaitu $40 \mathrm{~cm} \mathrm{x}$ $40 \mathrm{~cm}$ x $50 \mathrm{~cm}$. Bobot benih ditimbang menggunakan timbangan digital, sedangkan panjang diukur dengan menggunakan penggaris $30 \mathrm{~cm}$ dengan ketelitian $1 \mathrm{~mm}$. Terdapat 2 perlakuan dan 1 kontrol pada penelitian tentang pemuasaan benih ikan baung ini, yaitu perlakuan A: 1 hari puasa 1 hari diberi pakan, perlakuan B: 2 hari puasa 1 hari diberi pakan, dan kontrol (tiap hari diberi pakan). Pakan komersial dengan protein 30\% diberikan kepada benih ikan baung pada jam 06.00-24.00 dengan rentang waktu tiap 3 jam. Sampling pengukuran pertumbuhan bobot dan panjang dilakukan setiap sepuluh hari sekali dengan jumlah sampel 30 ekor/akuarium. Sintasan dihitung pada akhir perlakuan pemeliharaan untuk setiap perlakuan.

Pertumbuhan mutlak panjang dan bobot merupakan selisih dari panjang atau bobot akhir dan panjang atau bobot awal pemeliharaan. Pertumbuhan mutlak dihitung dengan rumus :

$$
\mathrm{PM}=\mathrm{Wt}-\mathrm{Wo}
$$

di mana :

$\mathrm{PM}=$ pertumbuhan mutlak

$\mathrm{Wt}=$ bobot rata-rata ikan pada saat akhir $(\mathrm{g})$

Wo = bobot rata-rata ikan pada saat awal $(\mathrm{g})$

Laju pertumbuhan bobot harian (LPH) dengan mengacu kepada rumus Weatherley \& Gill (1987) :

$$
\mathrm{LPH}=\frac{\ln \mathrm{Wt}-\ln \mathrm{Wo}_{\mathrm{o}}}{\mathrm{t}} \times 100 \%
$$

di mana :

$\mathrm{LPH}=$ laju pertumbuhan harian (\%)

Wt = bobot rata-rata ikan pada saat akhir $(\mathrm{g})$

Wo = bobot rata-rata ikan pada saat awal (g)

$\mathrm{t} \quad=$ lama perlakuan (hari)

Sintasan adalah persentase jumlah benih yang hidup pada akhir pengamatan dibandingkan jumlah larva pada awal pemeliharaan. Sintasan dihitung berdasarkan rumus :

$$
\text { Sintasan }(\%)=\frac{\mathrm{Nt}}{\mathrm{No}} \times 100 \%
$$

di mana :

$\begin{aligned} \mathrm{Nt}= & \begin{array}{l}\text { jumlah benih pada saat akhir pemeliharaan } \\ \text { (ekor) }\end{array} \\ \mathrm{No}= & \begin{array}{l}\text { jumlah benih pada saat awal pemeliharaan } \\ \text { (ekor) }\end{array}\end{aligned}$

Data yang diperoleh kemudian ditabulasi dan dianalisis statistik menggunakan bantuan program SPSS 22. Uji banding keragaman pertumbuhan dan sintasan diuji dengan ANOVA dan uji lanjut Duncan. 
Tabel 1. Pertumbuhan panjang dan bobot mutlak benih ikan baung

Table 1. Total weight and length gain of Asian redtail catfish's seedling

\begin{tabular}{lcc}
\hline $\begin{array}{c}\text { Perlakuan } \\
\text { Treatments }\end{array}$ & $\begin{array}{c}\text { Pertumbuhan panjang mutlak } \\
\text { Total length growth }(\mathbf{c m})\end{array}$ & $\begin{array}{c}\text { Pertumbuhan bobot mutlak } \\
\text { Total weight growth }(\mathrm{g})\end{array}$ \\
\hline Kontrol & $1.17 \pm 0.35^{\mathrm{a}}$ & $0.52 \pm 0.30^{\mathrm{a}}$ \\
A & $1.15 \pm 0.11^{\mathrm{ab}}$ & $0.52 \pm 0.09^{\mathrm{a}}$ \\
B & $0.94 \pm 0.49^{\mathrm{bc}}$ & $0.67 \pm 0.34^{\mathrm{b}}$ \\
\hline
\end{tabular}

\section{HASIL DAN BAHASAN}

\section{Pertumbuhan benih ikan baung}

Benih ikan baung kontrol memiliki pertumbuhan panjang tertinggi $(1,17 \pm 0,35 \mathrm{~cm})$ namun tidak berbeda nyata $(\mathrm{P}<0,05)$ dengan perlakuan $\mathrm{A}$ dan berbeda nyata dengan perlakuan B (Tabel 1). Sedangkan perlakuan A tidak berbeda nyata terhadap perlakuan B. Untuk pertumbuhan bobot ikan baung tertinggi didapatkan pada perlakuan $B$, nilai tersebut berbeda nyata dengan perlakuan A dan kontrol. Namun perlakuan A tidak berbeda nyata dengan kontrol.

Dari hasil penelitian menunjukkan bahwa ikan yang dipuasakan pada perlakuan 1 hari puasa 1 hari diberi pakan dan 2 hari puasa 1 hari diberi pakan mempunyai pertambahan panjang yang tidak lebih baik dan secara signifikan lebih rendah dibanding perlakuan ikan yang tidak dipuasakan (kontrol). Hal ini diduga, karena benih ikan baung yang dipuasakan mengalami pengurangan nutrisi yang digunakan sebagai pertumbuhan. Ikan membutuhkan makanan untuk mendapatkan energi tubuh dan ikan akan mengalami penurunan energi tubuh yang lebih nyata jika ikan dipelihara dalam waktu yang lebih lama dalam kondisi kelaparan (dipuasakan).

Berbeda dengan pertambahan panjang, hasil dari pengamatan pertambahan bobot menunjukkan bahwa benih ikan dipuasakan pada perlakuan 2 hari puasa 1 hari diberi pakan mempunyai pertambahan bobot yang secara signifikan sedikit lebih tinggi dibanding dengan perlakuan benih ikan yang tidak dipuasakan (kontrol) dan 1 hari puasa 1 hari diberi pakan. Keadaan ini diduga terjadi karena meskipun benih ikan baung yang dipuasakan mengalami pengurangan nutrisi yang digunakan sebagai pertumbuhan namun dalam kasus ini ikan baung tersebut banyak memakan sesamanya (kanibal). Dan sifat kanibalisme ini mengakibatkan ikan baung menjadi lebih ganas saat puasa dan pertambahan bobotnya menjadi lebih tinggi dibanding ikan yang rutin diberi pakan.

Laju pertumbuhan harian tertinggi diperoleh pada perlakuan $\mathrm{B}(0,95 \pm 0,34 \%)$ dan berbeda nyata $(\mathrm{P}<0,05)$ dengan kontrol $(0,66 \pm 0,34 \%)$ dan perlakuan A $(0,74 \pm 0,11 \%)$ (Gambar 1$)$. Laju pertumbuhan tersebut termasuk rendah, hal tersebut diduga karena kondisi akuarium yang kurang mendukung untuk proses pertumbuhan benih ikan. Sesuai dengan pernyataan Effendie (1997), bahwa pertumbuhan ikan dipengaruhi oleh beberapa faktor yaitu faktor internal dan eksternal. Faktor internal umumnya adalah faktor yang sukar dikontrol, di antaranya adalah keturunan, jenis kelamin, umur, parasit dan penyakit. Sedangkan faktor eksternal meliputi makanan dan suhu perairan. Suhu media pemeliharaan saat perlakuan yaitu berkisar antara $25^{\circ} \mathrm{C}$ sampai $30^{\circ} \mathrm{C}$, suhu ini masih sesuai dengan suhu optimal untuk ikan baung (Hemibagrus nemurus) (Khairuman \& Amri, 2010). Faktor lainnya yang berpengaruh terhadap pertumbuhan ikan adalah faktor dalam transformasi makanan menjadi jaringan tubuh ikan seperti jumlah pakan yang dikonsumsi, kecernaan makanan, laju pencernaan, frekuensi pemberian pakan, penyerapan zat makanan, serta efisiensi dan konversi pakan (Dharma \& Suhenda, 1986).

\section{Sintasan Benih Ikan Baung}

Sintasan benih ikan baung pada akhir penelitian yang dipelihara selama 30 hari disajikan pada Gambar 2. Hasil pengujian menunjukkan perlakuan kontrol memiliki sintasan yang berbeda nyata dengan perlakuan A dan perlakuan $\mathrm{B}$, dengan nilai berturut-turut sebagai berikut $91,11 \pm 3,05 \%, 63,55 \pm 12,74 \%$, dan 55,77 $\pm 4,04 \%$.

Hasil sintasan yang serupa diperoleh pada penelitian Bilton \& Robins (1973) yang melakukan penelitian pada ikan Fulton channel sockeye salmon. Hasil pada penelitian ini menunjukkan bahwa semakin lama waktu pemuasaan, sintasan menjadi semakin rendah. Nilai sintasan yang diperoleh dari hasil penelitian ini disebabkan sifat ikan baung termasuk ikan dengan sifat kanibal yang tinggi, sehingga ikan yang dipuasakan lebih lama bersifat agresif dan berpotensi tinggi terjadi kanibalisme antara masing-masing individu untuk memicu tingginya potensi kematian benih ikan, seperti yang terjadi pada penelitian Wang et al. (2000) yang menyatakan bahwa mortalitas benih ikan terjadi karena perilaku agresif ikan yang menyebabkan ikan lainnya mengalami luka yang akhirnya menyebabkan kematian.

\section{Implikasi bagi Pengembangan Budidaya Ikan Baung}

Hayward et al. (1997) menyatakan bahwa pertumbuhan kompensasi dapat digunakan sebagai alat manajemen untuk meningkatkan pertumbuhan, 


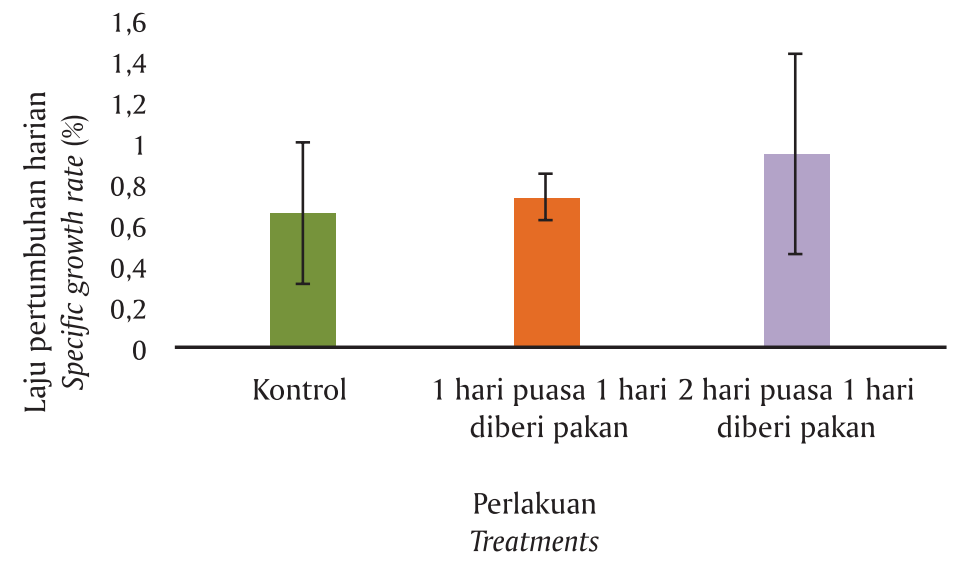

Gambar 1. Laju pertumbuhan harian benih ikan baung (Hemibagrus nemurus)

Figure 1. Specific growth rate of Asian redtail catfish (Hemibagrus nemurus)

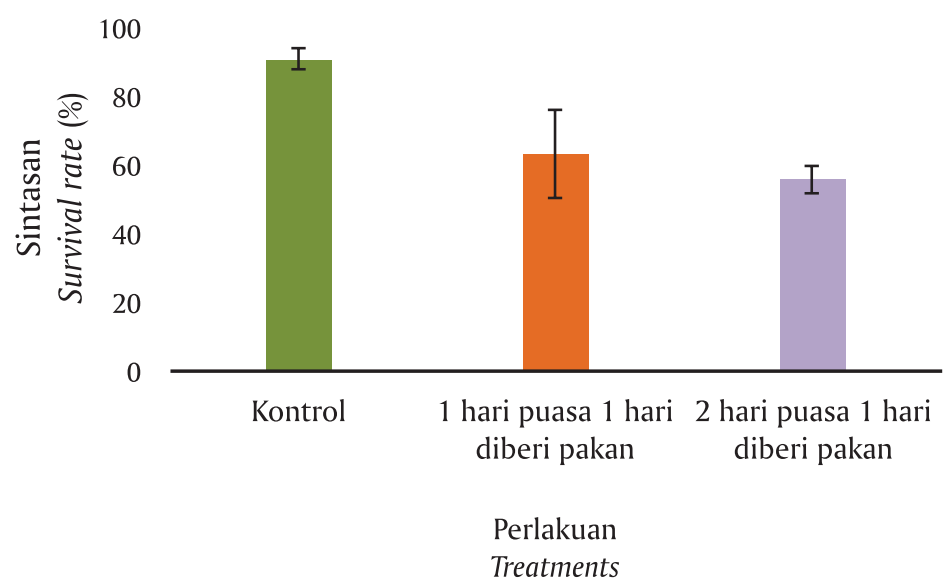

Gambar 2. Sintasan benih ikan baung (Hemibagrus nemurus)

Figure 2. Survival rate of Asian Redtail Catfish (Hemibagrus nemurus)

efisiensi pakan, dan juga mengurangi biaya pakan. Pada berbagai spesies ikan, strategi mengurangi atau membatasi jumlah pakan telah digunakan untuk merangsang terjadinya pertumbuhan kompensasi. Informasi hasil penelitian pada benih ikan baung ini dapat diimplikasikan sebagai acuan atau dasar dalam melakukan penelitian lanjutan untuk menentukan strategi pemberian pakan yang efektif dan efisien guna meningkatkan pertumbuhan ikan baung dan mengembangkan teknologi budidaya ikan baung.

\section{KESIMPULAN}

Benih ikan baung tidak dapat mencapai pertumbuhan kompensasi meskipun telah dipuasakan dalam waktu yang sangat singkat (1-2 hari). Pemuasaan juga berakibat pada semakin rendahnya tingkat sintasan benih ikan baung akibat kanibalisme.

\section{DAFTAR ACUAN}

Ali, M., Cui, Y., Zhu, X., \& Wootton, R.J. (2001). Dynamics of appetite in three fish species (Gasterosteus aculeatus, Phoxinus phoxinus, and Carassius auratus gibelio) after feed deprivation. Aquaculture Research, 32, 443-450.

Bilton, H.T., \& Robins, G.L. (1973). The effects of starvation and subsequent feeding on survival and growth of Fulton channel sockeye salmon fry Oncorhynchus nerka. Journal of the Fisheries Research Board of Canada, 30, 1-5.

Dharma, L., \& Suhenda, N. (1986). Pengaruh pemberian pakan dengan tangan dan alat self feeder terhadap pertumbuhan dan produksi ikan mas di kolam air deras. Bulletin Penelitian Perikanan Darat, 5(1), 7984. 
Dwiyono. (2004). Produksi pakan ikan dan pemberian pakan intensif pada ikan, Sulawesi Selatan. Balai Riset Perikanan Budidaya Air Payau Maros.

Effendie, H. (1997). Biologi perikanan. Yayasan Pustaka Nusantara. Bogor, $163 \mathrm{hlm}$.

Hayward, R.S., Noltie, D.B., \& Wang, N. (1997). Use of compensatory growth to double hybrid sunfish growth rates. Transactions of the American Fisheries Society, 126, 316-322.

Hitchcock, M.J. (2013). Side effects of feed restriction and compensatory growth in fish. Thesis. University of Otago. New Zealand, 182 pp.

Khairuman, \& Amri, K. (2010). Ikan baung, peluang usaha dan teknik budidaya intensif. PT. Gramedia Pustaka Utama. Jakarta, 88 hlm.
Sucipto, A., \& Prihartono, E. (2000). Pembesaran ikan baung (Hemibagrus nemurus). Penebar Swadaya. Jakarta, 110 hlm.

Walter, M., Trippel, E.A., \& Peck, M.A. (2013). Compensatory growth in young seedling Atlantic cod. Institute of Hydrobiology and Fisheries Science, University of Hamburg. Germany, ICES CM. E: 12.

Wang, Y., Cui, Y., Yang, Y., \& Cai, F. (2000). Compensatory growth in hybrid tilapia, Oreochromis mossambicus $\times$ 0 . niloticus reared in seawater. Aquaculture, 189, 101-108.

Weatherley, A.H., \& Gill, H.S. (1987). The biology of fish growth. Academic Press, Toronto. Canada, 443 pp. 
